\title{
FGFR1/2/3 Inhibitor HMPL-453
}

National Cancer Institute

\section{Source}

National Cancer Institute. FGFR1/2/3 Inhibitor HMPL-453. NCI Thesaurus. Code C150383.

An orally bioavailable inhibitor of the fibroblast growth factor receptor (FGFR) types 1, 2, and 3 (FGFR1/2/3), with potential antineoplastic activity. Upon administration, FGFR inhibitor HMPL-453 binds to and inhibits FGFR1/2/3, which may result in the inhibition of FGFR1/2/3-related signal transduction pathways. This inhibits proliferation in FGFR1/2/3overexpressing tumor cells. FGFR, a family of receptor tyrosine kinases (RTKs) upregulated in many tumor cell types, plays a key role in cellular proliferation, migration and survival. 